\title{
Launching a New Brand of Women's Underwear
}

\author{
Ivana KOJUNDZIC, Alica GRILEC, Ksenija DOLEZAL*, Irena SABARIC \\ University of Zagreb Faculty of Textile Technology, Department of Clothing Technology \\ ikojundzic@gmail.com, alica.grilec@ttf.hr, *ksenija.dolezal@ttf.hr, irena.sabaric@ttf.hr
}

\section{Professional paper}

UDC $658+687.2+339.138$

DOI: https://doi.org/10.31881/TLR.2018.vol1.iss2.p64-71.a5

Reveived 25 July 2018; Accepted 29 August 2018

\begin{abstract}
Women's underwear plays a significant role in everyday clothing. Underwear serves a number of equally important purposes. High aesthetic requirements have to be fulfilled as well as those of protection and comfort. Therefore, the idea of launching a new fashion brand of women's underwear is presented in this paper. The main purpose of the paper is the description of the development of a new brand of luxury underwear including the introduction of several economic phases which are cover mission, vision, brand goal, SWOT analysis and $7 P$ marketing mix.
\end{abstract}

\section{KEYWORDS}

Underwear, fashion brand, SWOT analysis, 7P marketing mix

\section{INTRODUCTION}

Underwear is classified as clothing items that are worn under the outerwear and is in direct contact with the body. Apart from protecting clothing, its purpose is to reduce friction between outerwear and skin, shape the body, and provide additional warmth if necessary. Underwear was first used to cover private parts and was made of natural materials such as leaves. Egyptian women were the first to wear underwear 3000 years BC [1]. Underwear was worn as protection from various epidemics in the past, but its role and shape changed by adapting to the trends throughout history. The purpose of underwear was often associated with emphasising certain body parts. For example, women wore tight corsets to emphasise their breasts in ancient Greece, Figure 2.

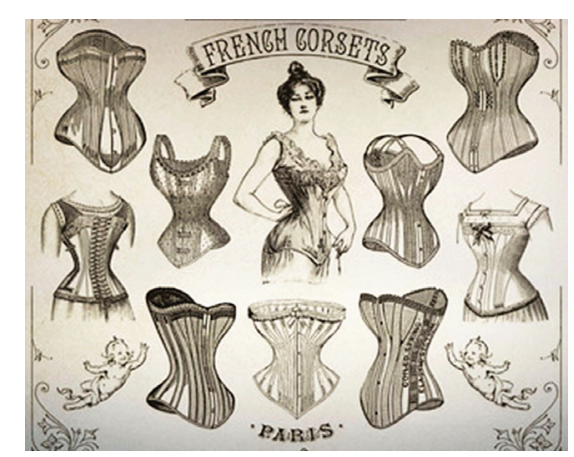

Figure 1. An example of bodice/corset from the $19^{\text {th }}$ century [2]

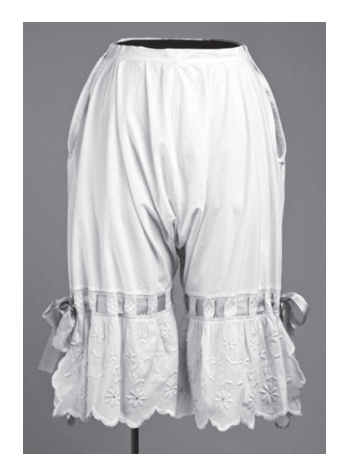

Figure 2. Source, $19^{\text {th }}$ century underwear-pants [3]

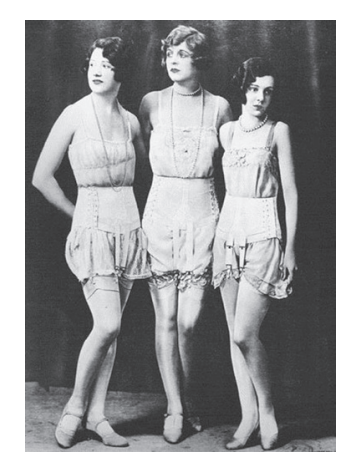

Figure 3. Examples underwear form 1920s [4] 
In other periods, underwear was used for covering the breasts so they would not stand out, emphasizing the back of the body and the hips, Figure 3, 4. Textile materials such as leather or linen were used for this purpose, as well as hoops from brushwood, wires or metal [1, 5].

Nowadays, underwear is made of high quality materials and the models are constructed and modelled to meet the current fashion trends and ensure the desired function, comfort and shape of the body [6].

\section{STARTING A NEW FASHION BRAND OF WOMAN'S UNDERWEAR}

Firstly, we analysed the existing underwear manufacturers in Croatia and their presence on the Internet, as well as the brands they developed. The economic sector of the underwear production in Croatia was analysed as shown in Tables 1 and 2. Only companies with 10 or more employees registered as clothing manufacturers were included (C14). Specifically, underwear manufacturers according to total revenue (from the top down) as presented in Table 1.

Table 1. Underwear manufacturers, Croatia 2018

\begin{tabular}{|c|c|c|c|}
\hline $\mathrm{Nr}$ & Company & Companies size & Nr of employees \\
\hline 1 & GALEB JSC & Medium & 404 \\
\hline 2 & HAKADESCH Ltd. & Small & 92 \\
\hline 3 & NEORES Ltd. & Small & 208 \\
\hline 4 & ORLJAVA Ltd. & Small & 351 \\
\hline 5 & MODEA NOVA Ltd. & Small & 143 \\
\hline 6 & POUNJE JSC & Medium & 31 \\
\hline 7 & PENIĆ TEXTIL EXPORT-IMPORT Ltd. & Small & 101 \\
\hline 8 & TEX Ltd. & Mikro & 15 \\
\hline 9 & MAKO Ltd. & Small & 44 \\
\hline 10 & MAIER-TEXTIL Ltd. & Small & 54 \\
\hline 11 & KETEKS Ltd. & Small & 58 \\
\hline 12 & MTČ Factory of tricot JSC & Small & 73 \\
\hline 13 & LAGOMAR Ltd. & Micro & 37 \\
\hline 14 & HAVA simple Ltd. & Micro & 37 \\
\hline 15 & I-KONG Ltd. & Micro & 42 \\
\hline 16 & ŠTIKMA Ltd. & Micro & 16 \\
\hline 17 & Misteks Pro Ltd. & Micro & 22 \\
\hline 18 & POUNJE KONFEKCIJA Ltd. & Micro & 44 \\
\hline 19 & Fashion stars simple Ltd. & Micro & 13 \\
\hline 20 & Privredno društvo Satina Ltd. & Micro & 10 \\
\hline
\end{tabular}

Source: Croatian Chamber of Commerce, 2018.

It is concluded there are 20 companies registered for underwear manufacturing in Croatia employing 10 or more employees. Only two are medium sized, nine are small sized, and nine are micro companies. Their brands, according to the Internet analysis, are presented in Table 2. 
Table 2. Underwear brands by Croatian manufacturers, 2018

\begin{tabular}{|c|c|c|c|}
\hline $\mathrm{Nr}$ & Company & Web Adress & Brands \\
\hline 1 & GALEB JSC & www.galeb.hr & Salele \\
\hline 2 & HAKADESCH Ltd. & Not Available & Data Not Available \\
\hline 3 & NEORES Ltd. & http://www.neores.hr/ & $\begin{array}{l}\text { Do not develop their own brands according } \\
\text { informations from their web site }\end{array}$ \\
\hline 4 & ORLJAVA Ltd. & http://www.orljava.hr/ & \\
\hline 5 & MODEA NOVA Ltd. & https://modea-nova.hr/ & \\
\hline 6 & POUNJE JSC & https://www.pounje.hr/ & $\mathrm{J}^{\circ}$ \\
\hline 7 & $\begin{array}{l}\text { PENIĆ TEXTIL } \\
\text { E EXPORT-IMPORT Ltd. }\end{array}$ & $\begin{array}{l}\text { http://www.penic-textil. } \\
\text { com/ }\end{array}$ & Data Not Available \\
\hline 8 & TEX Ltd. & https://tex-garesnica.hr/ & Data Not Available \\
\hline 9 & MAKO Ltd. & https://www.mako.hr/ & \\
\hline 10 & MAIER-TEXTIL Ltd. & http://maier-textil.hr/ & Data Not Available \\
\hline 11 & KETEKS Ltd. & Not Available & Data Not Available \\
\hline 12 & MTČ Factory of tricot JSC & http://mtcstrigova.hr/ & \\
\hline 13 & LAGOMAR Ltd. & Not Available & Data Not Available \\
\hline 14 & HAVA simple Ltd. & Not Available & Data Not Available \\
\hline 15 & I-KONG Ltd. & Not Available & Data Not Available \\
\hline 16 & ŠTIKMA Ltd. & http://stikma.hr/ & $\begin{array}{l}\text { Do not develop their own brands according } \\
\text { informations from their web site }\end{array}$ \\
\hline 17 & Misteks Pro Ltd. & Not Available & Data Not Available \\
\hline 18 & POUNJE KONFEKCIJA Ltd. & Not Available & Data Not Available \\
\hline 19 & Fashion stars simple Ltd. & $\begin{array}{l}\text { http://www.fashionstars. } \\
\text { com.hr/ }\end{array}$ & $\begin{array}{l}\text { Do not develop their own brands according } \\
\text { informations from their web site }\end{array}$ \\
\hline 20 & $\begin{array}{l}\text { Privredno društvo Satina } \\
\text { Ltd. }\end{array}$ & Not Available & Data Not Available \\
\hline
\end{tabular}

Source: authors

If we assume that companies with less than 10 employees do not produce large enough quantity of underwear to have a significant market share and, according to Table 2, we can conclude there are not a lot of Croatian underwear brands. This provides a possibility for success and positioning among Croatian underwear producers, as well as gaining a market share. Only six (out of 20 analysed) manufacturers have a visible brand presence on the Internet. Given the growing demands of the market for quality products and the lack of Croatian underwear manufacturers, the idea of launching a new line of luxury underwear has been 
developed. For the realization of this idea, it is necessary to include several economic phases important for brand development. The first step is to describe the company's potential business activities through its mission, vision, business goal, SWOT analysis and 7P marketing mix, supporting the viability of placing luxury underwear on the market. In addition, it is necessary to identify business objectives, advantages and disadvantages, as well as strengths, weaknesses, opportunities and threats to the business. By using a combination of marketing tools, the company would adapt to the requirements and characteristics of the target market, covering all elements of the 7P marketing mix: product to be placed on the market, price formation, promotion, type of distribution when entering the market, market placement process, people and physical environment, and finally, the target audience.

\section{THE ESTABLISHMENT OF NEW FASHION BRAND}

According to Easey, fashion marketing is defined as "the application of a range of techniques and a business philosophy that centres upon customer and potential customer of clothing and related products and services in order to meet the long-term goals of the organization" [7]. This is the reason why companies without strong vision, mission, and lasting value will be lost among the messages other brands send on the same market. A brand is the most valuable asset of a company and a satisfied customer is the key to long-term success. According to Burke, branding is defined as "the process a company uses to identify and communicate its product or services and provide customers with assurances of a level of quality and consistency of standard" [8]. There are two scenarios: placing a new product on the market or reminding the customers of the already existing one. In the first case, as presented in this paper, the company must offer unique solutions and show the customers that the new brand can satisfy their needs. In the second case, the customers just need to be reminded of the brand's presence on the market [9]. First of all, the importance of brands for both companies and customers needs to be defined. For companies, brands are: an identification tool for easier handling and monitoring, a means of legal protection of unique features, a symbol of certain level of quality. For the consumer, a product enrichment means for unique associations, a source of competitive advantage and financial income. For the clients, brands are: proof of originality of the product and company's responsibility, a way of reducing risk and product search costs, a promise, warranty or contract with the manufacturer of the product, a symbolic means and a sign of quality [10]. In order to start a new fashion brand and enter into a new business or to improve an already existing one, a detailed analysis of the planned activities and business environment needs to be conducted. Elaboration of external and internal analysis of the situation is required. Creating an internal situation analysis involves an analysis of the current level of development and management analysis in case that a company or brand already exists. External analysis comprises an analysis of external factors. In order to obtain a better quality analysis, it is necessary to understand a wide range of parameters. Competition analysis, as well as procurement and sales markets, are of great importance.

\section{VISION, MISSION AND GOALS OF A NEW COMPANY}

\section{Vision}

The main vision is to create a recognizable fashion brand of luxury underwear in Croatia expand to foreign markets, and become a synonym for luxury and luxurious underwear. The goal is to become the only Croatian fashion brand that manufactures and sells underwear made of high quality materials, such as silk, fur, lace, cotton and viscose which guarantee quality, durability and attractiveness of the product. 


\section{Mission}

The mission of the brand is to focus on quality and uniqueness, professional production, and availability to potential buyers. Furthermore, the mission is to demonstrate modern style, as well as inspiration from the past. In addition, the mission is to create a fashion brand of luxurious underwear with luxurious materials and details. The aim is to provide more prosperous clients with modern underwear made of high quality natural materials. Finally, the mission of the brand is to achieve recognition for the quality of production.

\section{Goals}

Short-term goal is to organise various events focusing on luxury aimed at attracting target audiences. The plan is to place the products on the domestic market, where there is currently minimal or no competition, and expand the assortment of products after a while. The first step is to employ persons with secondary and higher professional education in the field of textile and fashion design, and to procure the equipment for production. It is necessary to create a production line consisting of sewing machines, ironing machines, sewing equipment, materials and computers for performing administrative tasks. Long-term goal is to become the leading fashion house of luxurious underwear with its own store and custom-made production in Croatia as such a brand does not exist in the country. The main feature of the fashion brand would be quality and uniqueness. The underwear would be made in Croatia and the materials would be purchased at factories abroad. The possibility of custom-made production or repairs of purchased underwear would be offered to customers.

The target group are wealthy clients in all age groups, attracted by the quality of the material and the luxurious appearance of the underwear. Considering there is little luxurious underwear on the market, a high quality product assortment would be offered.

The goal of the brand is to develop and survive on the market as the leader in producing luxurious underwear, and to grow and expand into the regional and international market. Goal achievement is planned in 10 years.

\section{MATERIALS AND METHODS}

\section{SWOT analysis}

In addition, there are different methods and techniques of analysing company's internal and external environment. Based on these methods and techniques, the company identifies its place on the market and takes specific actions to improve its position. The SWOT analysis of the new company is presented in Table 1 , and was carried out to detect its strengths and weaknesses, as well as opportunities and threats to the company and the fashion brand.

Table 3. SWOT analysis of the new fashion brand

\begin{tabular}{|c|c|}
\hline $\begin{array}{c}\text { STHRENGHTS } \\
\mathrm{S}\end{array}$ & $\begin{array}{c}\text { WEAKNESES } \\
\text { W }\end{array}$ \\
\hline $\begin{array}{l}\text { Quality of production } \\
\text { Quality of materials } \\
\text { Unique production } \\
\text { Productive team and workers experience } \\
\text { Investment in Marketing and Promotion } \\
\text { Excellent relationship with suppliers } \\
\text { Good organization and leadership }\end{array}$ & $\begin{array}{l}\text { Limited market } \\
\text { The difficulty of entering the market } \\
\text { Initial low wages } \\
\text { Insufficient funding for promotion }\end{array}$ \\
\hline
\end{tabular}




\begin{tabular}{cc}
\hline OPPORTUNITIES & THREATHS \\
O & $T$ \\
\hline $\begin{array}{c}\text { Opportunity for entering the foreign market } \\
\text { Poor competition }\end{array}$ & $\begin{array}{c}\text { The weakening of customers purchasing power } \\
\text { Emigration of working-age population } \\
\text { Possibility of an economic crisis } \\
\text { Innovations }\end{array}$ \\
\hline
\end{tabular}

Based on the analysis, the conclusion is that the benefits of the business lie in customer satisfaction, quality of production and materials, and the quality of management and leadership. As for weaknesses, a limited market is mentioned as a small company requires a lot of effort for differentiation on the market. However, there is an emphasis on opportunities because the fashion brand can be recognized and it can gradually increase its market share, as well as expand its operations beyond the state borders. The main threat is the weak customers' purchasing power due to the high rate of displacement of working-age inhabitants of Croatia.

Based on the SWOT analysis of the initial business of the new company, the conclusion is that neutralize the weaknesses and moderate possible threats with its strengths. As part of the SWOT analysis, interviews were conducted with several entrepreneurs, design studio owners, and professors at the Faculty of Textile Technology in Zagreb. It was concluded that Zagreb, as the capital of Croatia, has a deficit of luxurious underwear designers, and that such a company will not have great competition. There is great potential for expansion across the whole region. There is also a high number of skilled personnel for production of underwear in Croatia because Croatia was once the capital of the textile and fashion industry in the former Yugoslavia. The interviewees emphasized that an increasing number of young people are launching their fashion brands and are trying to revive the fashion industry's famous era. In addition, more people decide to buy products from local designers. The interviewees highlighted problems of taking out loans and the lack of financial means which limit marketing communication. At present, the main threats are the unfavourable economic situation, the purchasing power of Croatia's inhabitants, and the placing of cheap products on the market, which are more affordable to the majority of people [11].

\section{P marketing mix of the fashion brand}

There are a number of activities in each company that affect customers, and the task of each of them is to create their own combination of activities. Such a combination of activities is called a marketing mix. In the early 1960s, professor Jerome McCarthy proposed a marketing mix consisting of four Ps, namely: Product, Price, distribution and selling Place, and Promotion. Each P covers several activities [12].

In recent times, the mix has expanded to seven Ps including: People, Process and Physical Evidence [13]. In the company presented in this paper, the products are luxurious underwear and the goal is to introduce other clothing items. What sets the new brand apart from the majority of other manufacturers' products is quality which ensures the products longevity and justifies the price. The products to be produced initially are: bras, panties of various kinds, corsets, neglige, baby doll dresses, bathrobes, thin silk dresses, nightgowns and silk pajamas, and, in time, luxurious silk and lace dresses for special occasions. The most popular products will be women's underwear made of lace and silk satin. The company will develop a very close relationship with its customers by fulfilling their wishes and offering custom-made production and product repairs. The product is the marketing mix element on which the new company largely relies [11]. The initial price of the product will be determined by "Market Skimming" policy. A high price of the product will be set in accordance with global competition and justified by the product's quality. The distribution of 
the product will be carried out by the company itself, in its own stores and own web page, as well as in a variety of concept stores across the state, and later in the region. The aim of the new company is to attract as many customers through different forms of promotion, TV advertising, fashion magazines, billboards, sponsorship of various events (concerts, fashion shows, in catering, tourism, exhibitions, etc.).

Active participation is planned in various exhibitions and competitions, as well as organizing fashion shows each season and fashion events when placing a new collection on the market. Different methods of payment will be possible, as well as the ability to test or try out the products for 14 days. Each product will be the best marketing tool. After that, an active website will be launched which would enable advertising and sales as well as getting customers' feedback. The best place to promote new products are social networks such as Facebook and Instagram [11] as digital communication today is one of the most dominant form of mass communication [14]. Mass media are the means of mass communication and are aimed at informing, educating, and entertaining users. Newspapers, television and radio are traditional mass media, while the internet is a new mass media that uses portals as substitute for newspapers. Nowadays, it is possible to watch television and listen to radio shows on the Internet, which means it unites all media and brings more information and content than traditional media [14]. Communication via electronic media is only slightly different from the usual communication model. While the communication process is the same, the participants and the devices used are different. Blogs, YouTube, Pinterest, and Instagram are some of the most popular digital media that influence the fashion industry today. Fashion blogs and YouTube fashion gurus have established relevance in the fashion world and affect the way businesses are advertised. They have built their own following and have the ability to launch or stop trends that are based on what they wear and publish on their social network accounts [15]. Facebook is still the most popular social network overall, but younger people mostly use Instagram or YouTube because they are much easier to use, give greater creative freedom to display content, and are less formal than Facebook. Statistics confirm that, currently, over two billion people use Facebook. YouTube has one and a half billion users, and Instagram has 900 million users [16].

The new fashion brand's underwear is primarily intended for women who value quality, love luxury, and can afford it. By wearing such items, they try to build a fashion- conscious image in society. Clients have to feel comfortable and satisfied while shopping which will be achieved by interior design. For this purpose, the prevailing colours highlighted on the logo will be golden, beige and off-white, Figure 4.

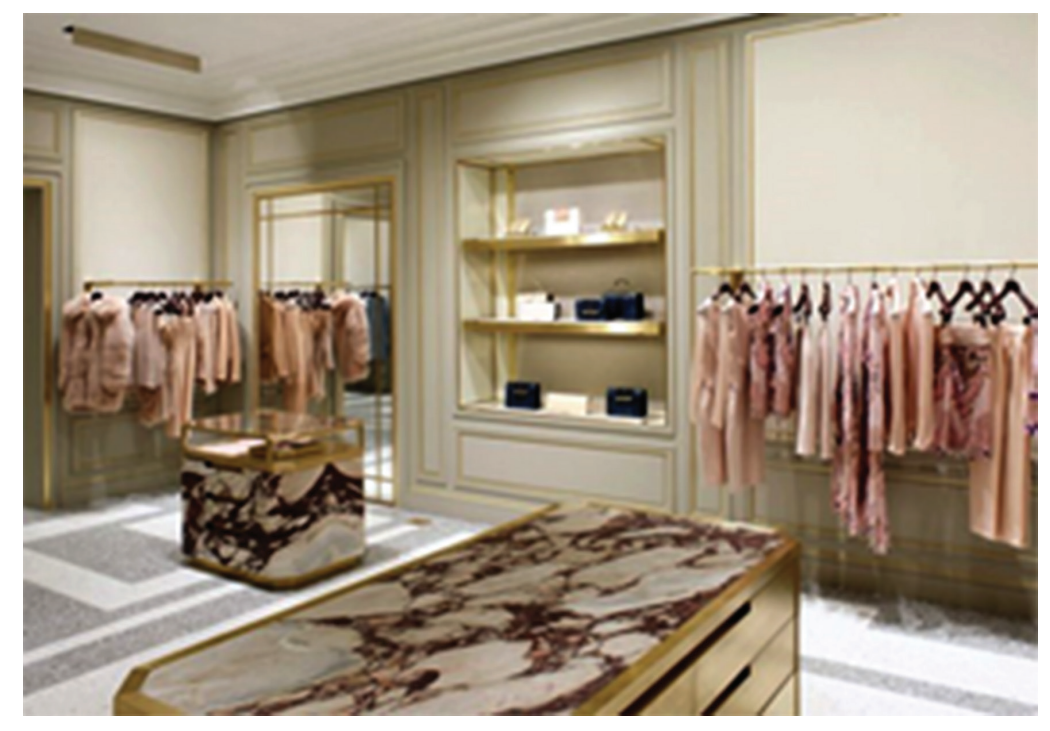

Figure 4. Example of shop decoration [11] 


\section{CONCLUSIONS}

By using contemporary economic methods and conducting needs analysis, the feasibility from idea to realization has been determined. Based on Swot and 7P marketing mix analyses, it has been confirmed that the new company has a good perspective for launching and developing a new fashion brand and surviving on the luxurious underwear market. Considering there is almost no competition, the new company has a great potential for success and the next step is to raise the initial capital for the realisation of this idea.

\section{REFERENCES}

[1] Dolezal K, Hrzenjak R, Kojundzic I. The impact of underwear on the shape of a woman's body. In: Savanovic G, editor. VI Scientific-vocational Conference with international participation „Development tendencies in the textile industry - Design, Technology, Management"; 2018; Beograd: The College of textile design, technology and management, 2018. p.106-109.

[2] Pinterest. Vintage corset ideas. [Image on internet]. 2017 [cited 2 May 2017]. Available from: https: // www.pinterest.com/pin/ 550142910710119600

[3] Pinterest. Women's fashion, 19 century fashion. [Image on internet]. 2017 [cited 21 May 2017]. Available from: https://www.pinterest.com/explore/19-century-fashion/

[4] McWha R. Vintage Underwear for a Vintage Fit [Internet].The Costume Rail: Costume, Couture and Vintage Sewing. [Cited 18 Jun 2017]. Available from: http://thecostumerail.blogspot.com/2013/02/ vintage-underwear-for-vintage-fit.html

[5] Thomass C, Örmen C. Povijest donjeg rublja. Zagreb: ALFA; 2011.

[6] Gertrud L. A History of Fashion in the 20th Century. Cologne: Könemann Verlagsgesellschaft mbH; 2000.

[7] Easey M, editor. Fashion marketing. $3^{\text {rd }}$ ed. Blackwell Publishing; 2009.

[8] Burke S. Fashion Entrepreneur: Starting Your Own Fashion Business. Burke Publishing; 2010.

[9] Malinowska-Olszowy M. Brand strategy in the Clothing and Textile Market. Fibres and Textles in Eastern Europe. 2005 Jan;13(1):8-10.

[10] Vranesevic T. Upravljanje markama Zagreb: Accent; 2007.

[11] Kojundzic I. Konstrukcija i modeliranje kolekcije luksuznog zenskog donjeg rublja [master's thesis]. Zagreb: Sveuciliste u Zagrebu Tekstilno-tehnoloski fakultet; 2017.

[12] Kotler P. Kotler o marketingu: kako stvoriti, osvojiti i gospodariti trzistima. Zagreb: Masmedia, Poslovni dnevnik; 2006.

[13] The Marketing Mix. Marketing Mix Definition of the 4P's and 7P's [Internet]. 2015 [Cited 25 Apr 2018]. Available from: http://marketingmix.co.uk

[14] Zgrabljic Rotar N, editor. Digitalno doba: masovni mediji i digitalna kultura. 1 izd. Zagreb: Naklada medijska istrazivanja; 2011.

[15] Huynh T. Fashion Forward: How Digital Media is Changing the Fashion Industry Refugee Marketing [Internet]. Refuge Integrated Marketing Strategies. 2016 [Cited 14 Apr 2018]. Available from: http:// refugemarketing.com/fashion-forward-how-digital-media-is-changing-the-fashion-industry/

[16] Statista: The Statistics Portal. Social Media Startistics \& Facts [Internet]. 2018 [Cited 10 Apr 2018]. Available from: https://www.statista.com/topics/1164/social-networks/ 